\title{
An Empirical Examination Of The Predictors Of Consumer Compulsive Buying As An "Impulse Control Disorder Not Otherwise Specified": A Branding Perspective
}

\author{
Richard Chinomona, Vaal University of Technology, South Africa
}

\begin{abstract}
While researches on consumer compulsive behaviour as a psychiatric problem have been steadily increasing, they seem to be a paucity of studies that investigate compulsive buying behaviour from a branding perspective. The present research is an attempt to fill this gap by examining the relative influence of four antecedents of compulsive buying behaviour - brand experience, brand satisfaction, brand trust and brand attachment on consumer compulsive buying behaviour, using a sample of consumers in Gauteng Province of South Africa. The central argument of this paper is that consumer compulsive buying behavior can be understood from the strength of branding outcomes. Four hypotheses are posited and in order to empirically test these hypotheses, a sample data set of 151 was used. Three hypotheses were supported while one (H1) was rejected. Drawing from the study findings, managerial implications are discussed and limitations and future research directions are suggested. On the overall, this study provide tentative empirical support that compulsive buying behaviour can be influenced by branding outcomes in Africa - a context that is often most less researched on.
\end{abstract}

Keywords: Brand Experience; Brand Satisfaction; Brand Trust; Compulsive Buying Behaviour; South Africa

\subsection{INTRODUCTION}

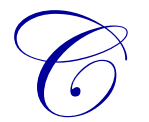

ompulsive buying has received increased research attention in the last decade (Claes, Bijttebier, Eynde, Mitchell \& Faber, 2010; Weaver, Moschis \& Davis, 2011). This has been partly due to the adverse psychological and financial consequences that have been associated with compulsive buying behaviour such as exacerbated negative emotions, strained interpersonal relationships, and financial debt (Kellett and Bolton, 2009). According to Dittmar (2004), it is estimated that compulsive buying behaviour occur in $2 \%$ to $16 \%$ of the general population and is increasingly recognized as a serious clinical problem requiring psychological and psychiatric treatment (Black, 2007; Croissant et al., 2009; Palan et al, 2011; Mueller et al., 2011). While studies such as one by Mueller et al., (2009) suggested that compulsive buying behaviour is associated with substantial psychiatric comorbidity, other researchers such as Smyth et al., (2007) suggested that compulsive buying behaviour might be the result of the interplay of several biological, psychological and sociological factors.

Compulsive buying behaviour has been defined differently by different researchers in academia. For instance, in psychiatric literature, Kraepelin (1915) use "onimania" to describe this behavior, while Bleuler (1924) use "buying mania" besides "onimania". Compulsive buying is medically defined as an impulse control dysfunction, a mental disorder characterized by irresistible impulses to engage in harmful or senseless behaviours (Palan et al, 2011). According to Croissant et al., (2009), compulsive buying in medical terms is classified as an "Impulse Control Disorder Not Otherwise Specified" according to ICD-10 and DSMIV. It is this disorder characterized by 
frequent, irresistible and senseless buying that lead to personal distress, social, marital, or occupational dysfunction, and to financial or even legal problems. Marketing scholars define compulsive buying behaviour as a chronic, repetitive purchasing that becomes a primary response to negative events or feelings (Black, 2007).

Drawing from the extant literature, the actual cause of compulsive behaviour is unknown (Marčinko, Bolanča \& Rudan, 2006). Some studies submit that, compulsive buying behaviour is triggered by negative mood states (e.g. depressed mood, anxiety, boredom) and result in overspending typically prompted by feelings of guilt, shame, and remorse (Miltenberger et al., 2003). Chronic and repetitive failure in self-regulation is considered as causal for the inappropriate purchasing behavior (Faber and Vohs, 2004; Kellett \& Bolton, 2009). Furthermore, endorsement of materialism appears an important underlying mechanism that may constitute a vulnerability factor with respect to compulsive buying (Dittmar, 2005). Researchers such as Mueller et al., (2010a), associate compulsive buying behaviour with psychiatric comorbidity, especially with depression, anxiety and impulsive behaviors such as binge eating while Billieux, Rochat, Rebetez, and van der Linden (2008) associated it with substance abuse, and other impulse control disorders. Nevertheless, whereas there is undisputable empirical evidence associate mainly psychological, biological or sociological factors as antecedents of compulsive buying behaviour, there seem to be a dearth of studies that investigated marketing issues such as branding as possible predictors of compulsive buying behaviour especially from an African perspective - South Africa in particular.

Against this backdrop, the current study is set to have the following four empirical objectives:

1. To investigate the influence of brand experience on compulsive buying behaviour

2. To investigate the influence of brand satisfaction on compulsive buying behaviour

3. To investigate the influence of brand trust on compulsive buying behaviour

4. To investigate the influence of brand attachment on compulsive buying behaviour

By and large, the current study findings are expected to contribute new knowledge to the existing body of psychology and compulsive buying behaviour literature in addition to providing practical implications to marketers and clinical psychologists in the context of a newly developed African country such as South Africa.

The remainder of this article will review the literature on brand experience, brand satisfaction, brand trust and brand attachment; then followed by a conceptual research model developed from the posited hypotheses. The study will also provide the research methodology, analyze data and present results. Finally, results are discussed, implications provided and limitations and future research directions highlighted.

\subsection{LITERATURE REVIEW}

\subsection{Affluenza Theory of Compulsive Buying}

According to Workman and Paper (2010), Affluenza theory builds on socio-cultural phenomenon that has been facilitated through contemporary marketing strategies. They suggest that shopping opportunities afforded by a market-based economy, combined with sufficient disposable income, appear to be necessary ingredients of compulsive buying. De Graff, Wann and Naylor (2005) first coined the term affluenza to describe compulsive buying behaviour as a psychological and social disease characterized by an over emphasis on cultural consumerism that "more is always better". It is regarded a psychological and socially transmitted condition of overload, anxiety, and waste resulting from the dogged pursuit of more (De Graaf, Wann \& Naylor, 2005). In other words, it is an addiction and a pernicious habit that is deeply rooted in the obsessive quest for more. According to Workman and Paper (2010) the advertising industry has trained consumers to solve problems with products, and they have been so successful at doing this that the majority of consumers are now hard wired to medicate any sense of uneasiness with their favorite drug - consumption. Thus, shopping has become consumer's programmed response to joy and sorrow, good fortune and bad, and despair and hope. As De Graaf, Wann, and Naylor (2005) pointed out shopping has become emotionally powered response to every life experience and is hence considered, substance abuse. Relating the Affluenza theory to the current study, this research submits that, compulsive buying behaviour is an uncontrollable and emotional addiction that is socially and externally induced, for instance through brands advertisement. Drawing from this reasoning, this study therefore contends that the consumers' brand trust, brand 
experience, brand satisfaction and brand attachment induced by excessive marketing gimmicks and branding strategies consequently culminate in consumer compulsive buying behaviour.

\subsection{Brand Experience}

Marketing academics and practitioners have acknowledged that consumers look for brands that provide them with unique and memorable experiences (Brakus et al., 2009). As a result, the concept of brand experience has become of great interest to marketers. Brand experience is conceptualized as sensations, feelings, cognitions, and behavioral responses evoked by brand-related stimuli that are part of a brand's design and identity, packaging, communications, and environments (Ha and Perks, 2005). According to Alloza (2008), brand experience can be defined as the perception of the consumers, at every moment of contact they have with the brand, whether it is in the brand images projected in advertising, during the first personal contact, or the level of quality concerning the personal treatment they receive. Brand experience is created when customers use the brand; talk to others about the brand; seek out brand information, promotions, and events, and so on (Ambler et al., 2002). Brand experience affects satisfaction, trust and loyalty. From the customer viewpoint, brands are relationship builders. As noted by Sahin, Zehir \& Kitapç (2011), there are five experiences, that is, sense, feel, think, act, and relate. The sense experience includes aesthetics and sensory qualities. Consistent with recent research in consumer behavior, the feel experience includes moods and emotions. The think experience includes convergent/analytical and divergent/imaginative thinking. The act experience refers to motor actions and behavioral experiences, such as relating to a reference group. In this study brand experience is defined as subjective, internal consumer responses (sensations feelings, and cognitions) and behavioral responses evoked by brand (Zarantenello \& Schmitt, 2000).

\subsection{Brand Satisfaction}

Brand satisfaction is defined satisfaction as a judgment that a brand or service feature, or the brand or service itself, provided or is providing a pleasurable level of consumption related fulfillment of needs or wants (Zboja \& Voorhees, 2006; Lin \& Wang, 2006). It is a result of a consumer's subjective evaluation that he/she is satisfied with the brands he/she selected or that the brands exceed his/her expectation. Brand satisfaction can be divided into the transaction-specific satisfaction and the accumulative satisfaction. The transaction-specific satisfaction refers to the evaluation and emotional reaction after the customers purchasing a recent transaction, and it is to seize the evaluation or feeling of the short-term and a particular experience. However, the accumulative satisfaction is an overall evaluation of the experience of purchasing or consuming to the product or service. Satisfaction has been identified as a reliable predictor of repurchase intentions (Cho et al., 2004; Cronin et al., 2000; Tian-Cole et al., 2002; Yoo, Cho, \& Chon, 2003). Consumers who satisfied tend to be highly committed to a brand and hence are likely to be tempted to repurchase compulsively (Cronin et al., 2000; Kelly \& Turley, 2001; Tian-Cole et al., 2002; Cho et al., 2004). This article defines brand satisfaction as subjective evaluation of the brands which the consumers selected achieving or surpassing their own expectation in certain specific transaction (Lee et al., 2011).

\subsection{Brand Trust}

Brand trust can be defined as the willingness of the average consumer to rely on the ability of the brand to perform its stated function (Chaudhuri \& Holbrook, 2001; Zhou et al., 2011). In order to avoid information asymmetry and uncertainty associated with purchasing new untested brands, some customers feel more comfortable by purchasing brands they trust (Chiu, Huang, \& Yen, 2010). In this case trust tends to decrease the uncertainty and information asymmetry related to other unfamiliar brands (Pavlou, Liang, \& Xue, 2007). In the literature, repeated interaction and long term relationships are introduced as keys to building trust (Wang \& Emurian, 2005). So if people realize the utilitarian and hedonic values of their brand their trust would increase and their love of the brand eventually might eventually induce impulsive buying behaviour in the future (Carroll \& Ahuvia, 2006; Zhou et al., 2011).

\subsection{Brand Attachment}

According to Tsai (2011), the idea of brand attachment is traceable back to the interpersonal attachment which theory asserts that human beings are born with an innate psychobiological system or an attachment behavioral 
system, which motivates them to become attached to significant figures such as a brand. However, according to Whang, Allen, Sahoury, and Zhang (2004) it is consumer passionate love which leads to brand attachment when there is right physical chemistry between the brand and the consumer, the brand and the consumer seem to be meant for each other, the brand fits the ideal standard of the consumer's self-image, and the consumer feels miserable if the brand is not available. On one hand, Carroll and Ahuvia (2006) reported that hedonism and self-expressiveness as the two salient factors for nurturing brand love and brand attachment. Hedonism characterizes exciting and delightful emotion, and self-expressiveness characterizes enforcement of self and social identities (Parish \& Holloway, 2010). Brand attachment rarely exists in the brand that is unable to induce hedonism and selfexpressiveness. On the other hand, Albert, Merunka, and Valette-Florence (2008) discovered brand/selfconnectedness to be the predictor of brand attachment. In other words, brand/self-connectedness translates into the personally relevant ties unbreakable by such situational factors as relative premium price or incidental product defects (Gillath, Shaver, Baek \& Chun, 2008). Such connectedness brings about the kind of relationships corresponding to the consumer's self-relevant needs in daily life. In this study brand attachment is defined as a durable emotional and psychological relation with the brand which results from the concomitance of friendship feelings and from brand dependence (Bell, 2010).

\subsection{Compulsive Buying Behaviour}

According to Dittmar (2005) compulsive buying has been a topic of psychology in "obsessive-compulsive disorder" for years, but has recently attracted the attention of marketing authors as well. Compulsive buying is medically defined as an impulse control dysfunction, a mental disorder characterized by irresistible impulses to engage in harmful or senseless behaviours (Palan et al, 2011). In conformity with the medical identification and previous explanations, marketing scholars use the term "compulsive buying" to define the behavior as "chronic, repetitive purchasing that becomes a primary response to negative events or feelings" (Mueller et al., 2010). It can be taken as a pathological or addictive issue, such as gambling (Ureta, 2007). Compulsive buying is characterized by an extreme pre- occupation with buying or shopping and by the frequent buying of items that are not needed and that are often not used (Muehlenkamp et al., 2009; Smyth et al., 2007). This maladaptive buying behavior causes chronic and significant individual, family, and social distress, and substantial financial problems (Kellett and Bolton, 2009). In this study, compulsive buying is defined as a response to an uncontrollable drive or desire to obtain, use, or experience a feeling, substance, or activity that leads an individual to repetitively engage in a behavior that will ultimately cause harm to the individual and/or to others (Koran et al., 2006; Mueller et al., 2010).

\subsection{CONCEPTUAL MODEL AND HYPOTHESIS DEVELOPMENT}

In order to empirically test the influence of brand experience, brand satisfaction, brand trust and brand attachment on consumer compulsive buying intention, a conceptual model is developed premised on the reviewed brand management literature. The conceptual model is grounded in the affluenza theory which provides a solid foundation for the current study. In this conceptualized model brand experience, brand satisfaction, brand trust and brand attachment are the predictors while consumer compulsive buying intention is the single outcome variable. Figure 1 depicts this conceptualized research model. The hypothesized relationships between the research constructs will be discussed hereafter. 


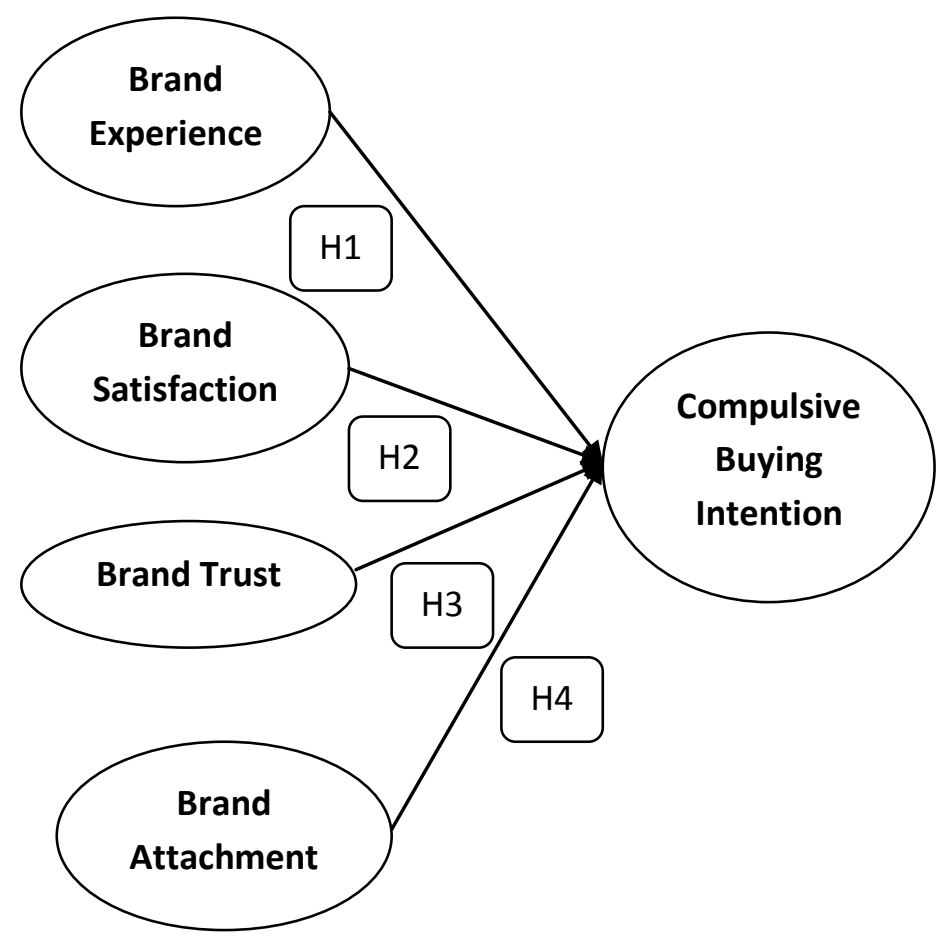

Figure 1: Conceptual Model

\subsection{Brand Experience and Compulsive Buying Behavior}

Consumer attitude towards certain brands which triggers a craving that leads to compulsive buying intention is formed after previous experience with consuming that brand (Palan et al, 2011). It is submitted that as consumers become familiar with a brand, the information gained from brand experience form the basis of future compulsive buying intention (Alloza, 2008; Muehlenkamp et al., 2009). Thus, brand experience, as a personal source of information, is likely to play an increasingly important role for enduring and emotional involvement that usually a result in habitual future repurchases (Mueller et al., 2010). Consistent with this notion are findings that show that the more frequent the prior positive brand experience, the stronger the positive brand attitude (Brakus et al., 2009; Sahin, Zehir \& Kitapç, 2011) and the greater the expected spontaneous respond that leads to compulsive buying. Therefore, it can be posited that the higher the level of positive brand experience by customers, the higher the expected customers' compulsive buying intention in South Africa. Drawing from the affluenza theory and prior empirical evidence, this study submit that:

H1: There is a positive relation between consumer brand experience and compulsive buying intention.

\subsection{Brand Satisfaction and Compulsive Buying Behavior}

A consumer who is satisfied with a certain brand is likely to be loyal to that brand (Agustin and Singh, 2005). According to Bosque and Martin (2008), brand satisfaction leads to attitudinal brand loyalty. Recent studies have demonstrated that attitudinal brand loyalty lead to affective reactions and often most sporadic future purchases (Zboja \& Voorhees, 2006; Algesheimer et al, 2005; Bennett et al, 2005) which insinuate compulsive buying intention. Therefore, drawing from this reasoning higher levels of brand satisfaction can be expected to lead to increased future compulsive buying intention. Previous empirical evidence has supported a positive linkage between brand satisfaction and compulsive buying behaviour (e.g. Lin \& Wang, 2006; Lee et al., 2011; Palan et al, 2011). Premised on the empirical evidence and the affluenza theory, this study therefore submits that brand satisfaction can be expected to lead to compulsive buying intention in the context of South Africa. Therefore, it can be postulated:

H2: There is a positive relation between consumer brand satisfaction and compulsive buying intention. 


\subsection{Brand Trust and Compulsive Buying Behavior}

Brand trust reduces the risks that a consumer attaches to a brand (Chiu, Huang, \& Yen, 2010). In addition to that, because the consumer trusts the brand, there will be no need for future information search when repurchasing the same brand (Pavlou, Liang, \& Xue, 2007). Besides, the extant literature notes that, brand trust is likely to evoke brand liking or love (Ashley \& Leonard, 2009). Consequently, the more a consumer love a brand the more likely the consumer will compulsively buy the brand. Hence, it can be posited that the higher the level of brand trust, the higher the expected level of consumer compulsive buying intention. Prior empirical evidence has found a positive association between brand trust and compulsive buying behaviour (for example, Narayanan \& Manchanda, 2010; Zhou et al., 2011). Therefore, based on affluenza theory and the empirical evidence this study posits that:

H3: There is a positive relation between consumer brand trust and compulsive buying intention.

\subsection{Brand Attachment and Compulsive Buying Behavior}

Researches in marketing seem to assert that attachment leads inalienable emotional reaction to a brand and express a psychological relation (e.g. Parish \& Holloway, 2010; Tsai, 2011). In other words, it is a durable emotional and psychological relation with the brand which results from the concomitance of friendship feelings and from brand dependence (Gillath, Shaver, Baek \& Chun, 2008). The brand attachment can be functional or existential. The latter is a reflection of emotional links that the consumer weaves with the brand over time (Tsai, 2011). According to Bell (2010), the consumer becomes attached to the brand among which the personality, the values and the image are in adequacy with self-concept hence triggering compulsive buying intention of that brand in any future purchases. Essentially, increases in brand attachment are therefore posited to be associated with increases in compulsive buying intentions in South Africa. This assertion is also supported with previous empirical evidence (e.g. Palan et al, 2011; Tsai, 2011). Thus, deducing from prior empirical evidence and the affluenza theory the following hypothesis is derived:

H4: There is a positive relation between consumer brand attachment and compulsive buying intention.

\subsection{RESEARCH METHODOLOGY}

\subsection{Sample and Data Collection}

The target population for the study was South African consumer in Gauteng who purchased any consumer goods. The sampling unit was the individual consumer. A mall intercept survey was used. This method has the advantage of speed, is less costly and the researcher has control over respondent type. Four shopping malls in Vanderbijlpark were selected for this survey. Students from the Vaal University of Technology were recruited as research assistants to distribute and collect the questionnaires. Of the total of 170 questionnaires distributed, 151 usable questionnaires were retrieved for the final data analysis, representing a response rate of 89 per cent. To eliminate differences in response patterns due to different reference points, all respondents were prompted to answer the questionnaire with reference to non-durable consumer goods. The reason for selecting this category was that consumers frequently purchase these products. In this regard, the respondents were asked to identify a product category in which they had frequently made a purchase intention decision. Respondents were then asked to name a brand in that category and they were requested to think about that brand as they complete the entire questionnaire, guided by the research assistants.

\subsection{Measurement Instrument and Questionnaire Design}

Research scales were operationalized on the basis of previous work. Proper modifications were made in order to fit the current research context and purpose. "Brand Experience" and "Brand Satisfaction" measures used twelve-item scale and eight-item scale measures respectively, all adapted from Sahina, Zehir \& Kitapçi, (2011). "Brand Attachment" used a four-item scale measure adapted from Tsai, (2011) while "Brand Trust" was measured using a three-item measurement scale adapted from He, Li \& Harris, (2012). "Compulsive Buying Intention" was measured using six instruments adapted from Kukar-Kinney, Ridgway \& Monroe, (2012). All the measurement 
items were measured on a five-point Likert-type scales that was anchored by $1=$ strongly disagree to $5=$ strongly agree to express the degree of agreement. Individual scale items are listed in the Appendix.

\subsection{DATA ANALYSIS RESULTS}

\subsection{Sample Characteristics and Descriptive Statistics}

Table 1 presents the description of the participants. The respondents were asked to report their demographic information, including gender, age, marital status and education. The respondents were predominantly females (57.6\%). The median age group of the respondent was that of less than 30 years (54.3\%). 57\% of the respondents were single. About $71 \%$ of the respondents had either high school $(43.7 \%)$ or university level of education $(27.2 \%)$ and the remainder had primary school (19.9) or postgraduate level of education $(0.09 \%)$.

Table 1: Sample Demographic Characteristics

\begin{tabular}{|l|c|c|}
\hline \multicolumn{1}{|c|}{ Gender } & Frequency & Percentage \\
\hline Male & 64 & $42.4 \%$ \\
\hline Female & 87 & $\mathbf{1 0 0 \%}$ \\
\hline Total & $\mathbf{1 5 1}$ & Percentage \\
\hline \multicolumn{1}{c|}{ Fge } & & $54.3 \%$ \\
\hline$\leqq 30$ & 82 & $33.8 \%$ \\
\hline $31-60$ & 51 & $11.9 \%$ \\
\hline$\geqq 60$ & 18 & $\mathbf{1 0 0 \%}$ \\
\hline Total Marital Status & $\mathbf{1 5 1}$ & Percentage \\
\hline & Frequency & $43.0 \%$ \\
\hline Married & 65 & $57.0 \%$ \\
\hline Single & 86 & $\mathbf{1 0 0 \%}$ \\
\hline Total & $\mathbf{1 5 1}$ & Percentage \\
\hline \multicolumn{1}{|c|}{ Level of Education } & Frequency & $19.9 \%$ \\
\hline Primary School & 30 & $43,7 \%$ \\
\hline High School & 66 & $27.2 \%$ \\
\hline University & 41 & $0.09 \%$ \\
\hline Postgraduate & 14 & $\mathbf{1 0 0 \%}$ \\
\hline Total & $\mathbf{1 5 1}$ & \\
\hline
\end{tabular}

\subsection{Structural Equation Modeling Approach}

In order to statistically analyze the measurement and structural models, this study used Smart PLS software for Structural Equation Modeling (SEM) technique (Ringle, Wende \& Will 2005). In SEM, the measurement model refers to the linkages between the latent variables and their manifest variables and the structural model captures the hypothesized causal relationships among the research constructs (Chin \& Newsted, 1999). SEM enables the simultaneous examination of both the path (structural) and factor (measurement) models in one model. In addition to that, Smart PLS combines a factor analysis with near regressions, makes only minimal assumptions, with the goal of variance explanation (high R- square) (Anderson, Schwager \& Kerns, 2006). Furthermore, Smart PLS supports both exploratory and confirmatory research, is robust to deviations for multivariate normal distributions, and is good for small sample size. Since the current study sample size is relatively small (151) Smart PLS was found more appropriate and befitting the purpose of the current study.

\subsection{Reliability Analysis for Dimensions and Items}

A measurement model of the conceptual model with five latent variables was estimated. All constructs were modelled using reflective indicators since the previous study have modelled them the same. Construct reliability was assessed using Composite Reliabilities (CR) values and Cronbach's Alpha (CA) values. As indicated in Table 2, the CR and the CA values are all above 0.7 recommended by Hulland (1999). With values ranging from 
0.837 to 0.910 for Composite reliability and from 0.829 to 0.923 for all Cronbach's alphas, this study can conclude that the scales are reliable.

Table 2: Accuracy Analysis Statistics

\begin{tabular}{|c|c|c|c|c|c|c|c|c|}
\hline \multicolumn{2}{|c|}{$\begin{array}{l}\text { Research } \\
\text { Construct }\end{array}$} & $\begin{array}{c}\text { LV Index } \\
\text { Value }\end{array}$ & $\begin{array}{c}\text { R-Squared } \\
\text { Value }\end{array}$ & $\begin{array}{c}\text { Cronbach's } \alpha \\
\text { value }\end{array}$ & $\begin{array}{c}\text { C.R. } \\
\text { Value }\end{array}$ & $\begin{array}{c}\text { AVE } \\
\text { Value }\end{array}$ & Communality & $\begin{array}{c}\text { Factor } \\
\text { Loading }\end{array}$ \\
\hline \multirow{3}{*}{ BA } & BA 2 & \multirow{3}{*}{4.281} & \multirow{3}{*}{0.000} & \multirow{3}{*}{0.837} & \multirow{3}{*}{0.829} & \multirow{3}{*}{0.619} & \multirow{3}{*}{0.617} & 0.716 \\
\hline & BA 3 & & & & & & & 0.784 \\
\hline & BA 4 & & & & & & & 0.853 \\
\hline \multirow{4}{*}{ BT } & BT 1 & \multirow{4}{*}{4.443} & \multirow{4}{*}{0.000} & \multirow{4}{*}{0.867} & \multirow{4}{*}{0.863} & \multirow{4}{*}{0.614} & \multirow{4}{*}{0.614} & 0.789 \\
\hline & BT 2 & & & & & & & 0.850 \\
\hline & BT 3 & & & & & & & 0.854 \\
\hline & BT4 & & & & & & & 0.619 \\
\hline \multirow{8}{*}{ BS } & BS 1 & \multirow{8}{*}{4.274} & \multirow{8}{*}{0.000} & \multirow{8}{*}{0.870} & \multirow{8}{*}{0.895} & \multirow{8}{*}{0.516} & \multirow{8}{*}{0.516} & 0.749 \\
\hline & BS 2 & & & & & & & 0.729 \\
\hline & BS 3 & & & & & & & 0.698 \\
\hline & BS 4 & & & & & & & 0.707 \\
\hline & BS 5 & & & & & & & 0.788 \\
\hline & BS 6 & & & & & & & 0.722 \\
\hline & BS 7 & & & & & & & 0.739 \\
\hline & BS 8 & & & & & & & 0.663 \\
\hline \multirow{12}{*}{ BE } & BE 1 & \multirow{12}{*}{4.394} & \multirow{12}{*}{0.000} & \multirow{12}{*}{0.910} & \multirow{12}{*}{0.923} & \multirow{12}{*}{0.500} & & 0.546 \\
\hline & BE 2 & & & & & & & 0.672 \\
\hline & BE 3 & & & & & & & 0.713 \\
\hline & BE 4 & & & & & & & 0.701 \\
\hline & BE 5 & & & & & & & 0.752 \\
\hline & BE6 & & & & & & & 0.736 \\
\hline & BE7 & & & & & & 0.500 & 0.738 \\
\hline & BE8 & & & & & & & 0.749 \\
\hline & BE9 & & & & & & & 0.726 \\
\hline & BE10 & & & & & & & 0.716 \\
\hline & BE11 & & & & & & & 0.715 \\
\hline & BE12 & & & & & & & 0.702 \\
\hline & CBI1 & & & & & & & 0.791 \\
\hline & CBI2 & & & & & & & 0.781 \\
\hline CPI & CBI3 & 400 & 050 & 088 & 086 & 507 & & 0.803 \\
\hline CBI & CBI4 & 4.499 & 0.959 & 0.858 & 0.856 & 0.592 & 0.592 & 0.844 \\
\hline & CBI5 & & & & & & & 0.798 \\
\hline & CBI6 & & & & & & & 0.565 \\
\hline
\end{tabular}

Note: $\mathrm{BA}=$ Brand Attachment; $\mathrm{BT}=$ Brand Trust; $\mathrm{BS}=$ Brand Satisfaction; BE = Brand Experience; $\mathrm{CBI}=\mathrm{Compulsive} \mathrm{Buying}$ Intention. C.R.: Composite Reliability; AVE: Average Variance Reliability. * Scores: 1 - Strongly Disagree; 3 - Neutral; 5 Strongly Agree

Convergent validity (internal consistence) was assessed using the average variance extracted (AVE) measure and Item loading values. According to Fornell and Lacker's (1981) the suggested benchmark should be 0.5 . As an be noted again in Table 2 and Figure 2, all the item loadings and AVE values reached the recommended benchmark - implying that all items converged well on the construct they were supposed to measure and hence confirming the existence of convergent validity.

\subsection{Inter-Construct Correlation Matrix}

To assess discriminant validity the AVE of the construct should be greater than the shared variance between the construct and the other model constructs (Chin, 1998). Table 3 lists the correlation matrix with correlation among constructs and the square root AVE on the diagonal. 
Table 3: Inter-Construct Correlations and Shared Variance

\begin{tabular}{|c|c|c|c|c|c|}
\hline Research Constructs & BA & BT & BS & $\mathbf{B E}$ & CBI \\
\hline Brand Attachment (BA) & 0.787 & & & & \\
\hline Brand Trust (BT) & 0.600 & 0.718 & & & \\
\hline Brand Satisfaction (BS) & 0.590 & 0.703 & 0.784 & & \\
\hline Brand Experience (BE) & 0.549 & 0.687 & 0.693 & $\mathbf{0 . 7 0 7}$ & \\
\hline Compulsive Buying Intention (CBI) & 0.604 & 0.701 & 0.704 & 0.672 & 0.769 \\
\hline
\end{tabular}

Note: $\mathrm{BA}=$ Brand Attachment; BT = Brand Trust; BS = Brand Satisfaction; BE = Brand Experience; $\mathrm{CBI}=\mathrm{Compulsive} \mathrm{Buying}$ Intention. Diagonal elements are the square root of Average Variance Extracted. The other values are the inter-construct correlations.

As shown in Table 3, the diagonal elements are greater than the off-diagonal elements in the corresponding rows and columns, therefore confirming that discriminant validity indeed exist.

\subsection{Structural Modeling Results}

The structural model was tested using the loadings and significance of the path coefficients (indicate the strengths of relationships between dependent and independent variables), and the $\mathrm{R}^{2}$ value (the amount of variance explained by independent variables). The statistical significance of each path was estimated using a Smart PLS bootstrapping method utilizing 300 resamples to obtain t-values (Chin, 1998). Figure 2 and Table 4 presents the results of the PLS analysis on the structural model along with the path estimates and t-values. Support for the study hypotheses, which are labeled on their corresponding paths in Figure 2, could be ascertained by examining the directionality (positive or negative) of the path coefficients and the significance of the t-values. The standardized path coefficients are expected to be at least 0.2 , and preferably greater than 0.3 (Chin 1998).

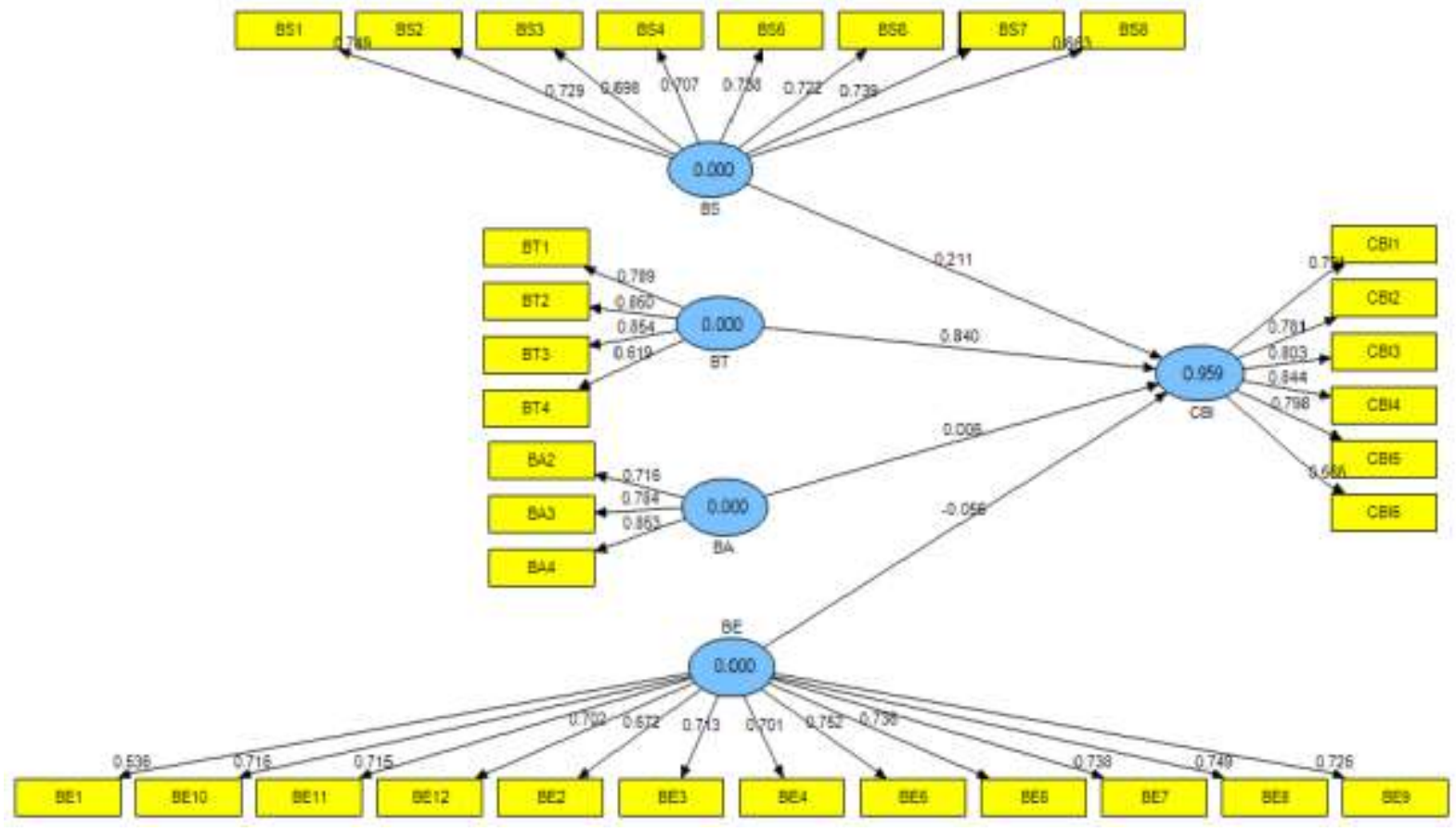

Figure 2: Measurement and Structural Model Results

Note: $\mathrm{BA}=$ Brand Attachment BT $=$ Brand Trust; BS = Brand Satisfaction;

$\mathrm{BE}=$ Brand Experience $\mathrm{CBI}=$ Compulsive Buying Intention.

The $\mathrm{R}^{2}$ value for the one dependent variable - compulsive buying intention (CBI) is 0.959 . This result reveal that, on the overall brand experience, brand satisfaction, brand trust and brand attachment altogether explains about the $95.9 \%$ of the variance in compulsive buying intention (CBI), hence suggesting that these variables almost fully explained the variations in compulsive buying intention among consumers. 
Table 4: Results of Structural Equation Model Analysis

\begin{tabular}{|l|c|c|c|c|}
\hline \multicolumn{1}{|c|}{ Proposed Hypothesis Relationship } & Hypothesis & $\begin{array}{c}\text { Path } \\
\text { Coefficients }\end{array}$ & T-Statistics & $\begin{array}{c}\text { Rejected / } \\
\text { Supported }\end{array}$ \\
\hline Brand Experience (BE) $\rightarrow$ Compulsive Buying Intention (CBI) & H1 & $\mathbf{- 0 . 0 5 5}$ & $\mathbf{1 . 6 6 3}$ & $\begin{array}{c}\text { Rejected } \\
\text { Supported }\end{array}$ \\
Brand Satisfaction (BS) $\rightarrow$ Compulsive Buying Intention (CBI) & H2 & $\mathbf{0 . 2 1 1}$ & $\mathbf{5 . 2 3 3}$ \\
\hline Brand Trust (BT) $\rightarrow$ Compulsive Buying Intention (CBI) & H3 & $\mathbf{0 . 8 4 0}$ & $\mathbf{2 8 . 3 9 5}$ & Supported \\
\hline Brand Attachment (BA) $\rightarrow$ Compulsive Buying Intention (CBI) & H4 & $\mathbf{0 . 0 0 6}$ & $\mathbf{0 . 1 9 1}$ & Supported \\
\hline
\end{tabular}

Note: $\mathrm{BA}=$ Brand Attachment; BT = Brand Trust; BS = Brand Satisfaction; BE = Brand Experience; CBI = Compulsive Buying Intention.

Smart PLS software does not provide goodness-of-fit measures for the full path model as like LISREL and AMOS, but it provides only $\mathrm{R}^{2}$ values for the dependent variables. However, a method to calculate a global goodness-of-fit (GoF) measure was proposed by Amato, Vinzi and Tenenhaus (2004), and this method takes into account both the quality of the measurement model and the structural model (Tenenhaus, Vinzi, Chatelin \& Lauro, 2005; Streukens, 2008). The global goodness-of-fit (GoF) statistic was calculated using the following equation:

$\mathrm{GoF}=\sqrt{\overline{\mathrm{AVE}} * \overline{\mathrm{R}^{2}}}$

Where $\overline{\mathrm{AVE}}$ represent the average of all AVE values for the research variables while $\overline{\mathrm{R}}^{2}$ represents the average of all $\mathrm{R}^{2}$ values in the full path model.

The calculated global goodness of fit $(\mathrm{GoF})$ is 0.54 , which exceeds the recommended threshold of GoF > 0.36 suggested by Wetzels, Odekerken-Schröder \& van Oppen (2009). Thus, this study concludes that the research model provides an overall goodness of fit.

\subsection{DISCUSSION OF RESULTS}

The results in Table 4 and Figure 2 provide support for four (4) hypotheses (H2, H3, H4, and H5) and reject one hypothesis (H1). Hypothesis 1 posited a positive relationship between brand experience and compulsive buying intention. However, the result in Table 4 and Figure 2, indicates that they is a negative $(\beta=-0.055)$ but insignificant $(\mathrm{t}=1.663)$ relation between brand experience and compulsive buying intention. Therefore, $\mathrm{H} 1$ is rejected. Hypothesis 2 posited a positive association between brand satisfaction and compulsive buying intention. Consistent with Hypothesis 2, results indicated that higher levels of brand satisfaction will lead to higher levels of compulsive buying intention $(\beta=0.211 ; \mathrm{t}=5.233)$. The standardized coefficients of brand image and brand trust $(\beta=0.840 ; \mathrm{t}=$ 28.395 ) is positive and significant. This is consistent with the prediction of $\mathrm{H} 3$ and is supported. Thus, a higher level of brand image is associated with higher levels of brand trust. Finally, results in Table 4 and Figure 2, are in line with $\mathrm{H} 4$ and support the reasoning that the higher the level of brand trust the customers have, the higher their brand loyalty $(0.006 ; \mathrm{t}=0.191)$. Therefore, $\mathrm{H} 4$ is strongly supported.

On the overall, the results of this study support the previous research findings which have found a positive relationship between brand satisfaction, trust, attachment and compulsive buying intention (for example, Tsai, 2011; Narayanan \& Manchanda, 2010; Lin \& Wang, 2006; Palan et al, 2011). However, the relationship between brand experience and compulsive buying intention which was posited to be significantly positive was found to be negative and insignificant. This is in contrast with previous empirical evidence (e.g. Sahin, Zehir \& Kitapç, 2011) and the current study proposition.

\subsection{Theoretical and Practical Implications of the Study}

While there is an increased recognition of compulsive buying behaviour as a serious clinical problem "Impulse Control Disorder Not Otherwise Specified", that require psychological and psychiatric treatment (Black, 2007; Croissant et al., 2009; Palan et al, 2011; Mueller et al., 2011), the extant literature is replete with empirical evidence suggesting that compulsive buying behaviour might be the result of the interplay of several biological, psychological and sociological factors. However, the current study is a departure from this long held conventional 
wisdom and attempts to investigate this contentious issue from a marketing perspective. In particular, a successful attempt was made in this study to attribute compulsive buying behaviour as interplay of or branding phenomena. In addition to that, the current study investigate this contentious issues in an often most neglected research context the African setting. Therefore, the findings of this empirical study are expected to provide fruitful new insights and implications to both academicians and practitioners across the globe.

On the academic side, this study makes a significant contribution to the brand management literature by systematically exploring the impact of branding outcomes on compulsive buying behaviour in context of South African - one of the newly developed countries on the African continent. In particular, the current study findings provide tentative support to the proposition that brand satisfaction, brand trust and to a lesser extent brand attachment should be recognized as antecedents and tools that foster consumer compulsive buying behaviour.

On the practitioners' side, important influential role of branding outcomes on compulsive buying behaviour in an African context are highlighted. Therefore, this study for instance submits that clinical psychologists seeking to find remedies to compulsive buying behaviour should begin to consider this problem not only as the interplay of psychological and sociological factors but also a marketing or branding driven matter. However, what the clinical psychologists ought to prescribe in light of this new evidence is possibly another grey area that might warrant future research inspection.

\subsection{Limitations and Future Research}

Although this study makes significant contributions to both academia and practice, it was limited in some ways, and therefore some future research avenues are suggested. First, the data were gathered from Gauteng Province of South Africa and the sample size of 150 is relatively small. Perhaps, the results would be more informative if the sample size is large and data gathered from the other eight provinces of the country are included. Therefore, future studies may be conducted by using data from other provinces in South Africa. Second, perhaps too, future studies should not be limited to South Africa, but rather consider extending this research to other African countries such as Zimbabwe for results comparison. Future studies can also extend the current study conceptual framework by studying the effects of a larger set of variables. For instance, the influence of brand identity, brand preference, and brand loyalty could be investigated. Above and beyond, this will immensely contribute new knowledge to the existing body of branding and consumer compulsive behaviour literature in the African setting - a research context which happens to be neglected in academics.

\subsection{SUMMARY OF RESEARCH RESULTS AND INTERPRETATION}

The purpose of this study was to investigate the influence of brand attachment, brand trust, brand satisfaction and brand experience on compulsive buying intention. In particular, four hypotheses were postulated. To test the proposed hypotheses, data were collected from Gauteng Province in South Africa. The empirical results supported the two posited research hypotheses in a significant way, while one hypotheses (H4), although supported was insignificant. However, H1 which hypothesized to be positive was found to be negative and insignificant. This means that those consumers who trust a certain brand or are satisfied with a brand are more likely to engage in compulsive buying intention.

Important to note about the study findings is the fact that brand trust has the strongest influence on consumer compulsive buying intention $(0.840)$ and followed by brand satisfaction $(0.211)$. The paradox is on brand experience which was found to be negatively related to compulsive buying intention. One might expect that the more experience in a brand especially positive experience a consumer has, the higher the likelihood of compulsive buying behaviour, hence a positive association. However, this was not the case. Perhaps this could be explained by the fact that if one is to make a decision based on previous experience, then that decision should factor in rationality, and yet compulsive buying behaviour is irrational by its nature - hence the negative relationship found in the current study. 


\section{AUTHOR INFORMATION}

Dr. Richard Chinomona is a Senior Lecturer and Facilitator of Research Methodology at Vaal University of Technology, Faculty of Management Sciences - Department of Logistics. He is a holder of six degrees and has published extensively in various international peer-reviewed journals. E-mail: rchinos@hotmail.com

\section{REFERENCES}

1. Agustin C. \& Singh J. (2005). Curvilinear Effects of Consumer Loyalty Determinants in Relational Exchanges, Journal of Marketing Research, (XIII).

2. Albert, N, Merunka, D., \& Valette-Florence, P. (2008). When consumers love their brands: Exploring the concept and its dimensions. Journal of Business research, 61(11), 1062-1075.

3. Algesheimer, R., Dholakia, U.M., \& Herrmann, A. (2005). The Social Influence of Brand Community; Evidence From European Car Clubs. Journal of Marketing, 69, 19-34.

4. Alloza, A. (2008). Brand Engagement and Brand Experience At BBVA, The Transformation of a 150 Years Old Company. Corporate Reputation Review, 11(4): 371-381.

5. Amato. S., Esposito V.V. \& Tenenhaus, M. (2004). A global goodness-of-fit index for PLS structural equation modeling, France: Oral Communication to PLS Club, HEC School of Management.

6. Ambler, T., Bhattacharya, C.B., Edell, J., Keller, K.L., Lemon K.N., \& Mittal, V. (2002). Relating Brand And Customer Perspectives On Marketing Management. Journal of Service Research, 5, 261-280.

7. Anderson, J., Schwager, P., \& Kerns, R. (2006). The drivers for acceptance of tablet PCs by faculty in a college of business. Journal of Information Systems Education, 17(4), 429-440.

8. Ashley, C. \& Leonard, H.A. (2009). Betrayed by The Buzz? Covert Content and Consumer-Brand Relationships. Journal of Public Policy and Marketing, 28(2): 212-220.

9. Bell, D. C. (2010). The dynamics of connection: How evolution and biology create care-giving and attachment. Lanham, MD: Lexington.

10. Bennet, R., Hartel, C.J.H., \& Mccoll-Kennedy, J.R. (2005). Experience as a Moderator of Involvement and Satisfaction on Brand Loyalty in a Business-to-Business Settings. Industrial Marketing Management, 34, 97-107.

11. Bennett, R., \& Rundle, T.S. (2005). The Brand Loyalty Life Cycle: Implications for Marketers. Brand Management, 12(4): 250-163.

12. Black, D.W. (2007). A Review of Compulsive Buying Disorder. World Psychiatry, 6(1): 14-18.

13. Bleuler, E. (1924). Textbook of Psychiatry. Macmillan: New York.

14. Billieux, J., Rochat, L., Rebetez, M.M.L., \& van der Linden, M. (2008). Are all facets of impulsivity related to self-reported compulsive buying behavior? Personality and Individual Differences, 44(6): 14321442.

15. Bosque, I.R., \& Martin, H.S. (2008). Tourist satisfaction a cognitive-affective model. Annals of Tourism Research, 35(2): 551-573.

16. Brakus, J.J., Schmitt, B.H. and Zarantonello L. (2009). Brand Experience; What Is It? How Is It Measured? Does It Affect Loyalty? Journal of Marketing, 74, 52-68.

17. Carroll, B.A., \& Ahuvia, A. (2006). Some Antecedents and Outcomes of Brand Love. Marketing Letters, 17(2): 79-89.

18. Claes, L., Bijttebier, P., Eynde, R.V.D., Mitchell, J.E., \& Faber, R., Zwaan, M., \& Mueller, A. (2010). Emotional reactivity and self-regulation in relation to compulsive buying. Personality and Individual Differences, 49(5), 526-530.

19. Chaudhuri, A., \& Holbrook, B.M. (2001). The Chain of Effects From Brand Trust and Brand Affects to Brand Performance: The Role of Brand Loyalty. Journal of Marketing, 65, 81-93.

20. Chin, W.W. (1998). Issues and opinion on structural equation modelling, MIS Quarterly, 22(1), 7-16.

21. Chin, W.W, \& Newsted, P.R. (1999). Structural Equation Modeling analysis with Small Samples Using Partial Least Squares. In Rick Hoyle (Ed.), Statistical Strategies for Small Sample Research, Sage Publications, pp. 307-341. Thousand Oaks, CA: Sage.

22. Chiu, C. M., Huang, H. Y., \& Yen, C. H. (2010). Antecedents of online trust in online auctions. Electronic Commerce Research and Application, 9, 148-159. 
23. Choi, K-S., Cho, W-K., Lee, S., Lee, H. \& Kim, C. (2004). The relationships among quality, value, satisfaction and behavioral intention in health care provider choice: A South Korean study. Journal of Business Research, 57, 913-921.

24. Cronin, J.J., Brady, M.K., \& Hult, T.M. (2000). Assessing the effects of quality, value, and customer satisfaction on consumer behavioral intentions in service environments. Journal of Retailing, 76(2), 193218.

25. Croissant, B., Klein, O., Löber, S., \& Mann, K. (2009). A case of compulsive buying--impulse control disorder or dependence disorder? Psychiatry Research, 36(4):189-192.

26. De Graaf, J., Wann, D., \& Naylor, T.H. (2005). Affluenza: the all consuming epidemic, 2nd edition, Berrett-Koehler Publishers: San Francisco.

27. Dittmar, H., Long, K., \& Meek, R. (2004). Buying on the Internet: Gender difference in on-line and conventional buying motivations. Sex Roles, 50, 423-444.

28. Dittmar, H. (2005). Compulsive buying - a growing concern? An examination of gender, age, and endorsement of materialistic values as predictors. British Journal of Psychology, 96(4): 467-491.

29. Faber, R., \& Vohs, K.D. (2004). To buy or not to buy? self-control and self-regulatory failure in purchase behavior. In R. F. Baumeister \& K. D. Vohs (Eds.), Handbook of self-regulation: Research, theory and application (pp. 509-524). NY: Guilford Press.

30. Fornell, C., \& Larcker, D.F. (1981). Evaluating structural equation models with unobservable variables and measurement error. Journal of Marketing Research, 27, 39-50.

31. Gillath, O., Shaver, P.R., Baek J.M., \& Chun, S.D. (2008). Genetic correlates of adult attachment style. Personality and Social Psychology Bulletin, 34, 1396-1405.

32. Ha, Y.-H., \& Perks, H. (2005). Effects of Consumer Perceptions of Brand Experience on The Web: Brand Familiarity, Satisfaction and Brand Trust. Journal of Consumer Behaviour, 4(6): 438-42.

33. Hulland, J. (1999). Use of Partial Least Squares (PLS)' in Strategic Management Research: A Review of Four Recent Studies. Strategic Management Journal, 20(2): 195-204.

34. Kellett, S., \& Bolton, J.V. (2009). Compulsive buying: A cognitive-behavioural model. Clinical Psychology \& Psychotherapy, 16(2): 83-99.

35. Kelly, S. W, \& Turley, L. W. (2001). Consumer perceptions of service quality attributes at sporting events. Journal of Business Research, 54, 161-166.

36. Koran, L.M., Aboujaoude, E., Ward, H., Shapira, N.A., Sallee, F.R., Gamel, N., \& Elliott, M. (2006). Pulse-Loaded Intravenous Clomipramine in Treatment-Resistant Obsessive-Compulsive Disorder. Journal of Clinical Psychopharmacology, 26(1): 79-83.

37. Kraepelin, E. (1915). Psychiatrie: Ein lehrbuch (8th ed., Vol. 4). Leipzig, Germany: Barth.

38. Lee, M. K. O., Shi, N., Cheung, C. M. K., Lim, K. H., \& Sia, C. L. (2011). Consumer's decision to shop online: The moderating role of positive informational social influence. Information and Management, 48 , 185-191.

39. Lin, H. H., \& Wang, Y. S. (2006). An examination of the determinants of customer loyalty in mobile commerce contexts. Information and Management, 43(3), 271-282.

40. Marčinko D, Bolanča M, Rudan V. (2006). Compulsive Buying and Binge Eating Disorder - A Case Vignettes. Progress in Neuropsychopharmacology and Biological Psychiatry, 30, 1542-1544.

41. Miltenberger, R.G., Redlin, J., Crosby, R., Stickney, M., Mitchell, J., Wonderlich, S., Faber, R., Smyth, J. (2003). Direct and retrospective assessment of factors contributing to compulsive buying. Journal of Behavior Therapy and Experimental Psychiatry, 34, 1-9.

42. Muehlenkamp, J.J., Engel, S.G., Wadeson, A., Crosby, R.D., Wonderlich, S.A., Simonich, H., Mitchell, J.E. (2009). Emotional states preceding and following acts of non-suicidal self-injury in bulimia nervosa patients. Behaviour Research and Therapy, 47, 83-87.

43. Mueller, A., Mitchell, J.E., Crosby, R.D., Gefeller, O., Faber, R.J., Martin, A., Bleich, S., Glaesmer, H., Exner, C., \& Zwaan, M. (2010). Estimated prevalence of compulsive buying in Germany and its association with sociodemographic characteristics and depressive symptoms. Psychiatry Research, 180(23), 137-142.

44. Mueller, A., Claes, L., Mitchell, J.E., Faber, R.J., Fischer, J., \& Zwaan, M. (2011). Does compulsive buying differ between male and female students? Personality and Individual Differences, 50(8): 13091312 . 
45. Narayanan, S., \& Manchanda, P. (2010). Heterogeneous learning and the targeting of marketing communication for new products. Marketing Science, 28(3), 424-441.

46. Palan, K.M., Morrow, P.C., Trapp, A. (2011). Compulsive Buying Behavior in College Students: The Mediating Role of Credit Card Misuse. The Journal of Marketing Theory and Practice, 19(1): 81-96

47. Parish, J. T., \& Holloway, B. B. (2010). Consumer relationship proneness: A reexamination and extension across service exchanges. Journal of Services Marketing, 24(1), 61-73.

48. Pavlou, P. A., Liang, H., \& Xue, Y. (2007). Understanding and mitigating uncertainty in online exchange relationships: A principal-agent perspective. MIS Quarterly, 31(1), 105-136.

49. Ringle, C. M., Wende, S., \& Will, A. (2005). SmartPLS 2.0 M3. Available at http:// www.smartpls.de

50. Sahin, A., Zehir, C., \& Kitapçi, H. (2011). The Effects Of Brand Experiences, Trust And Satisfaction On Building Brand Loyalty; An Empricial Research On Global Brands, The 7th International Strategic Management Conference, Paris-France.

51. Salinas, E. M., \& Perez, J.M.P. (2009). Modeling the brand extensions' influence on brand image. Journal of Business Research, 62, 50-60.

52. Smyth, J. M. (2007). Beyond self-selection in video game play: An experimental examination of the consequences of massively multiplayer online role-playing game play. Cyber-Psychology \& Behavior, 10(5), 717-727.

53. Streukens, S. (2008). On the use of partial least squares path modeling in organizational research: an overview and illustration of its possibilities. Working Paper, Hasselt University, Hasselt.

54. Tenenhaus, M., Vinzi, V. E., Chatelin, Y. -M., \& Lauro, C. (2005). PLS Path Modeling. Computational Statistics and Data Analysis, 48(1), 159-205.

55. Tian-Cole, S. T., Crompton, J. K., \& Willson, V. L. (2002). An empirical investigation of the relationships between service quality, satisfaction and behavioral intentions among visitors to a wildlife refuge. Journal of Leisure Research, 34, 1-24.

56. Tsai, S-P. (2011). Fostering international brand loyalty through committed and attached relationships. International Business Review, 20, 521-534.

57. Ureta, I.G. (2007). Addictive Buying Causes, Processes, and Symbolic Meanings (Thematic Analysis of a Buying Addiction Diary. Spanish Journal of Psychology, 10(2): 408-422.

58. Wang, Y. D., \& Emurian, H. H. (2005). An overview of online trust: Concepts, elements, and implications. Computers in Human Behavior, 21(1), 105-125.

59. Weaver, S.T., Moschis, G.P., \& Davis, T. (2011). Antecedents of materialism and compulsive buying: A life course study in Australia. Australasian Marketing Journal (AMJ), 19(4): 247-256.

60. Wetzels, M., Odekerken-Schröder, G., \& Van Oppen, C. (2009). Using PLS path modeling for assessing hierarchical construct models: guidelines and empirical illustration. Management Information Systems Quarterly, 33(1), 177-195.

61. Whang, Y. O., Allen, J., Sahoury, N., \& Zhang, H. (2004). Falling in love with a product: The structure of a romantic consumer-product relationship. Advances in Consumer Research, 31(1), 320-327.

62. Workman, L., \& Paper, D. (2010). Compulsive Buying: A Theoretical Framework. The Journal of Business Inquiry, 9(1): 89-126.

63. Yoo, Y. S., Cho, K. M., \& Chon, S. S. (2003). The effect of customer satisfaction on repurchase intention at golf practice ranges in South Korea. Korean Journal of Sport Management, 7(2), 1-13.

64. Zarantenello L, Schmitt BH (2000). Using the brand experience scale to profile consumers and predict consumer behavior. Brand Management, 17(7): 532-540.

65. Zehir, C., Sahin, A., Kitapci, H., \& Ozsahin, M. (2011). The Effects Of Brand Communication And Service Quality In Building Brand Loyalty Through Brand Trust; The Empirical Research On Global Brands, The 7th International Strategic Management Conference, Paris-France.

66. Zboja, J.J. and Voorhees, C.M. (2006). The impact of brand trust and satisfaction on retailer repurchase intentions. Journal of Services Marketing, 20(5): 381-90.

67. Zhou, Z., Zhang, Q., Su, C., \& Zhou, N. (2012). How do brand communities generate brand relationships? Intermediate mechanisms. Journal of Business Research, 65(7): 890-895. 


\section{APPENDIX: MEASUREMENT INSTRUMENTS}

\section{Brand Experience}

This brand makes a strong impression on my visual sense or other senses.

I find this brand interesting in a sensory way.

This brand does not appeal to my senses.

This brand induces feelings and sentiments.

I do not have strong emotions for this brand.

This brand is an emotional brand.

I engage in physical actions and behaviors when I use this brand.

This brand results in bodily experiences.

This brand is not action oriented.

I engage in a lot of thinking when I encounter this brand.

This brand does not make me think.

This brand stimulates my curiosity and problem solving.

\section{Brand Satisfaction}

I am very satisfied with the service provided by this brand.

I am very satisfied with this brand.

I am very happy with this brand.

This brand does a good job of satisfying my needs.

The service-products provided by this brand is very satisfactory.

I believe that using this brand is usually a very satisfying experience.

I made the right decision when I decided to use this brand.

I am addicted to this brand in some way.

\section{Brand Trust}

I trust this brand.

I rely on this brand.

This is an honest brand.

This brand is safe.

\section{Brand Attachment}

I am strongly passionate about the brand.

The brand induces strong passion in me.

I long to put the brand into my possession.

I may make necessary sacrifices to acquire the brand.

\section{Compulsive Buying Intention}

My closet has unopened shopping bags in it.

Others might consider me a "shopaholic".

Much of my life centres around buying things.

Buy things I don't need.

Buy things I did not plan to buy.

I consider myself an impulse purchaser. 


\section{NOTES}

